\title{
GENDER DI DUNIA ISLAM
}

\author{
Indira Fatra Deni P.
}

Dosen Fakultas Dakwah dan Komunikasi UIN Sumatera Utara

\begin{abstract}
Abstraksi
Seiringdenganperkembanganzaman yang semakinmengurastenaga dan pikiran dalam memaknai hidup yang dinamis. Membuat manusia secara otomatis tertuntut untuk melakukan hal-hal yang dianggap perlu dan penting untuk dilakukan. Baik dalam kehidupanberagama, berbangsadan bernegara. Dimana permasalahanyang semakin mencolokditengah-tengahkita hari ini adalah kesetaraangenderyang dianggapperlu untuk dipertanyakan mengingatbanyaknya tuntutan kehidupanyang memaksauntuk melakukannya.Pada kesempatankali ini penulismengupassedikittentangpemahaman genderyang sama-sama telah kita ketahui menjadipembahasanpentingdikalangan kaum akademik.

Pembahasandan penafsirangenderterusmenjadiperdebatanpanjang di berbagaikalangan, elitpolitik, agama, budaya, sosial serta civitasakademik. Merekamenganggapproblematika ini layak diperbincangkandi ranah merekamasing-masing.Olehkarenanya, dari sudut pandangyangberbedapulalah terkadangpemahamanini terlihatbias dan sedikitmengarah kepada kepentinganmasing-masing. Sepertidi Indonesiasetiap ada calon pemimpin daerah bahkan pusat yang perempuanselalu mengetengahkanperkataan emansipasi wanita dan merekajuga berhak tampil di depan publik berkecimpungbahkan tidak anyar berharap menjadi orang nomor satu di negeri multi budaya ini.
\end{abstract}

Kata Kunci: Gender, Dunia, dan Islam

\section{A. Pendahuluan}

Banyak sekali pengertian gender dari berbagai tokoh dan ilmuan yang dapat kita lihat. Namun di sini ada beberapa defenisi yang dapat menjadi acuan kita terhadap pemahaman kata gender tersebut. Secara bahasa gender berasal dari bahasa Inggris, gender artinya jenis kelamin. Sedangkan istilah gender menurut Webster'sNewDictionaryadalah sebagai perbedaan yang tampak pada pria dan wanita dilihat dari segi nilai dan tingkah laku. ${ }^{1}$

Didalam Women'sStudiesEncyclopediadijelaskan bahwa gender adalah suatu konsep kultural yang berupa memuat pembedaan dalam hal peran, perilaku, mentalita dan karakteristik emosional antara pria dan wanita yang berkembang dalam masyarakat. ${ }^{2}$ Gender yang

${ }^{1}$ Hasbi Indra, Potret Wanita Shaleha, (Jakarta: Penamadani, 2004), h. 242

${ }^{2}$ Ibid., h. 243 
mengacu pada peran dan tanggung jawab laki-laki dan perempuan yang terjadi akibat dari dan dapat berubah oleh keadaan sosial dan budaya masyarakat. Hal ini menunjukkan bahwa gender merupakan hasil bentuk ketentuan kehidupan sosial dan bukan biologis. ${ }^{3}$

Sedangkan menurut lips mengartikan gender sebagai cultural espectations for women and men. Atau harapan-harapan budaya terhadap laki-laki dan perempuan. ${ }^{4}$

Dari pengertian diatas menggambarkan adanya upaya untuk mengetahui perbedaan yang jelas antara kecendrungan pria dan wanita sekaligus pula menjelaskan bahwa isu gender berasal dari tradisi barat yang berusaha untuk memposisikan perbedaan pria dan wanita dalam interaksi sosial mereka dalam masyarakat.

Gender merupakan konsep yang mengacu pada peran dan tanggung jawab lakilaki dan perempuan yang terjadi akibat dari dan dapat berubah oleh keadaan sosial dan budaya masyarakat. Kesetaraan gender adalah kesamaan kondisi bagi laki-laki dan perempuan untuk memperoleh kesempatan dan hak-haknya sebagai manusia, agar mampu berperan dan berpartisipasi dalam kegiatan politik, ekonomi, sosial-budaya, pertahanan dan keamanan nasional dan kesamaan dalam menikmati hasil pembangunan tersebut.

\section{B. Latar Belakang Gender}

Kata gender telah digunakan di Amerika tahun 1960-an sebagai bentuk perjuangan secara radikal, konservativ, sekuler dan agama untuk menyuarakan eksistensi perempuan yang kemudian melahirkan kesetaraan gender. Menurut Eline Sholwalter (1989) bahwa wacana gender baru mulai berkembang pada tahun 1977 ketika kelompok feminis London meninggalkan isu-isu lama yang disebut dengan patriacal ${ }^{5}$. Diskriminasi hukum dan perlakuan norma budaya Arab sebelum Islam datang terhadap perempuan sangat membuat ingatan mereka berfikir untuk tidak kembali lagi ke zaman tersebut. Ditandai dengan memaksakan kaum yang termarjinalkan ini untuk angkat bicara dan berjuang demi mengharapkan penghargaan dan apresiasi positif dari kaum Adam bahwa perempuan juga dapat melakukan dan ikut membaur dalam dunia sosial baik di kancah politik, sistem ekonomi, sosial budaya dan lain-lain. Gender dan emansipasi perempuan merupakan jawabannya.

Islam sebagai agama yang kompleks yang memiliki kandungan yang sempurna dalam segala hal tak luput juga menyinggung tentang peran serta wanita dalam berprikehidupan sehari-hari. Hal ini di tegaskan oleh rasullullah sebagai perantara Alquran kepada umatnya dengan mengangkat harkat dan martabat wanita ketika itu. Sebelum Islam datang wanita menjadi sumber malapetaka bagi kaum Yahudi saat itu. Bahkan sangat

\footnotetext{
${ }^{3}$ Katimin, Mozaik Pemikiran Islam, (Bandung: Cita Pustaka Media Perintis, 2010), h. 296

${ }^{4}$ Lips, Hilary M. Sex \& Gender An Intruduction (London: Mayfield Publishing Company, 1993), h. 4

${ }^{5}$ Ch. Mufidah, Psikologi Keluarga Islam: Berwawasan Gender (Yogyakarta: UIN Malang Press, 2008). h. 1.
} 
tidak berprikemanusiaannya lagi mereka dengan teganya membunuh dengan cara mengubur hidup-hidup bayi perempuan mereka, dan perbuatan itu sangat dilarang di dalam Islam, yang juga sebagai agama Rahmatan lil'alamin. Mereka berpendapat bahwa wanita hanya membawa sial dan malapetaka bagi kelurga dan daerah sekitar mereka. Pemahaman yang berpendapat lagi dengan ekstrimnya menganggap wanita adalah sumber dosa yang menjadikan Adam sebagai manusia penghuni surga diturunkan ke bumi akibat hawa yang berjenis kelamin wanita.

Kehadiran Islam sebagai petunjuk dan aturan kehidupan manusia saat itu sangat dinanti oleh kaum yang termrjinalkan tersebut. Seakan memang telah datang kabar gembira di tengah kegelapan pola pikir manusia kala itu. Kegiatan yang bersifat domestik pun kian terbantahkan dengan lantunan keindahan ayat Allah dalam Alquran. Pembebasan kekangan yang sangat mentuhankan para kaum adam berubah secara sudut pandang kehidupan sosial namun tidak menampik pula bahwa ada hal-hal yang bersifat biologis yang memang tidak mungkin dapat disetarakan dengan laki-laki.

Pemahaman yang mengatakan kutukan terhadap perempuan kini terbalik dengan pemahaman Islam menjadi kelebihan dan keungulan perempuan terhadap laki-laki. Seperti, hamil, menyusui, melakukan pelayanan seksual yang diminta para lelaki menjadi ibadah propesionalnya perempuan. Bahkan terkadang proses alamiah itu mengalahkan perintah kewajiban manusia terhadap Tuhannya. Wanita yang sedang menyusui dan hamil tidak masalah untuk tidak menunaikan ibadah puasa saat itu jika memang ketika dia berpuasa dapat terjadi hal-hal yang mengakibatkan keburukan baginya. Begitu juga dengan saat menstruasi, mereka mendapatkan dispensasi khusus dalam hal ibadah. Di dalam buku karangan Prof. Katimin dituliskan bahwa kala itu yang banyak mengusik dan berjuang untuk gender adalah para Alkitab, karena dalam dunia Islam telah diterangkan tentang peran fungsi dan tanggung jawab setiap perempuan. Dan didukung oleh DUHAM (Daklarasi Universal Hak Azasi Manusia) yang disahkan oleh PBB pada 10 desember 1948.

Sejumlah penulis Kristen berpendapat bahwa, memang sifat alamiah kaum wanita untuk melayani orang lain, terutama suami dan anak-anaknya. Stephen Clark cukup lama bertahan pada pendapatnya yang mengatakan bahwa Allah telah menciptakan perbedaanperbedaan diantara kedua jenis kelamin sebagai pelengkap satu sama lain, agar mereka cocok dalam peran-peran berbeda. Dengan demikian dia dapat mengatakan bahwa kaum wanita memiliki kecendrungan alamiah untuk mengajar dan merawat anak-anak kecil. ${ }^{6}$

Teori mengatakan bahwa kedua jenis kelamin memiliki perbedaan, tetapi yang menarik perhatian orang banyak adalah kualitas dan peran masing-masing yang saling melengkapi. Seperti contoh seorang lelaki yang ulet bekerja keras yang melindungi seorang yang mengurusinya sepenuh hati oleh seorang istri atau ibu yang baik hati.

${ }^{6}$ Amne Borroedale, Tugas Rangkap Wanita: Mengubah Sikap Orang Kristen, (Jakarta: PT. BPK Gunung Mulia, 1997), h. 13. 
Namun disaat ini seiring dengan perkembangan zaman yang modern memaksa kaum intelaktual untuk mengupas dan membahas lebih dalam lagi peranan perempuan dalam kesetaraan jenis kelamin (gender). Persoalan perempuan sampai saat ini masih menjadi wacana serius untuk didiskusikan, selain karena terus mengalami perkembangan, juga banyak permasalahan perempuan tidak pernah habis. oleh suatu masa atau zaman kehadirannya di permukaan bumi, hal ini sangat tampak ketika dibicarakan tentang rendahnya sumberdaya perempuan, masalah kekerasan pada perempuan yang marak terjadi baik di ranah publik atau sektor-sektor lainnya. Semuanya menuntut adanya perhatian dan perjuangan serius oleh semua Stakeholder yang ada, terlebih dari kelompok perempuan sendiri.Seiring dengan perjalanan pembangunan yang sarat dengan perubahan-perubahan mendasar, baik pada tingkat paradigmatik maupun implementatif, dengan sebuah gerakan reformasi yang mengarah pada sistem demokrasi berkelanjutan guna terciptanya mekanisme desentralistik dengan mempertimbangkan potensi-potensi daerah dalam managerial sistem pemerintah daerah (Otonomi Daerah), merupakan peluang dan harapan besar bagi pengembangan potensi-potensi dasar perempuan dalam berbagai organisasi sosial kemasyarakatan yang mempunyai kekuatan basis massa pada tingkat bawah.

Di samping merupakan tantangan bagi pengelolaan organisasi terhadap minimnya sumber daya manusia yang selama ini pada tingkat nasional cukup memprihatinkan, dan ini menggambarkan bahwa kualitas sumber daya manusia Indonesia "perempuan" perlu ditingkatkan, perjuangan perempuan tidak pernah usai, meskipun kesempatan dan peluang selalu ada, hal ini disebabkan oleh kuatnya bangunan sosial masyarakat terhadap perempuan serta pemberian segala bentuk kesan yang mendistorsi terhadap kemajuan dan pemberdayaan perempuan, disamping minimnya sumber daya perempuan yang menyebabkan kondisinya semakin marginal oleh sistem dan budaya patriakhi yang mengarah pada mekanisme sistem kehidupan sosial bermasyarakat, dan anehnya kondisi ini terkadang didukung dan diciptakan oleh diri "perempuan" sendiri. Padahal saat sekarang di kota makin banyak wanita memperoleh kebebasan, baik berpolitik, pendidikan dan lain-lain. ${ }^{7}$

Sebuah proses panjang yang pada akhirnya dapat memiliki dan meraih kesempatan bagi para perempuan Indonesia untuk tetap maju dan terus meningkatkan pengetahuan dan pendidikan melalui jalur lembaga pendidikan formal ataupun organisasi-organisasi yang berkembang dalam kehidupan masyarakat, karena tidak sedikit yang dapat diperoleh dalam berpartisipasi aktif dalam berorganisasi, selain pengalaman langsung serta nilainilai kehidupan sosial masyarakat yang banyak berkembang dalam berorganisasi. Lembaga atau organisasi apapun yang dipilih para perempuan dalam mengaplikasikan potensipotensi dirinya, mempunyai makna sesuai dalam peningkatan sumber daya manusia serta partisipasi dalam menciptakan iklim kehidupan yang lebih kondusif. Sehingga organisasi perempuan apapun bentuknya bukan sekedar wadah yang akan mengumpulkan atau

${ }^{7}$ Maria Ulfa Subadio, Peranan Dan Kedudukan Wanita Indonesia. Cet IV, (Yogyakarta: Gajah Mada University Press, 1994) h. 351. 
memberdayakan potensi-potensi perempuan yang semakin ketinggalan, karena banyak hal yang dapat dilakukan oleh para aktivis perempuan secara kolektif apabila ingin maju dan ikut serta menyelesaikan ketimpangan-ketimpangan sosial yang bermuara pada ketidakadilan dan kesetaraan gender dalam kehidupan.

Kemudian ketika kita melihat bahwa pelaksanaan hukum bagi perempuan telah mengalami perubahan yang cukup berarti dalam masa yang lalu. Ketentuan-ketentuan Alquran tetap sangat berpengaruh dalam membentuk hukum-hukum baru sebagaimana pada pilihan-pilihan personal pria dan wanita muslim. Dikatakan bahwa Alquran sendiri telah memperbaharui kondisi wanita Arab pra Islam, dan dalam kenyataan telah meletakkan sebuah aturan yang didalamnya wanita dilindungi dan diberi hak tanggung jawab yang jelas. ${ }^{8}$

\section{Tokoh-Tokoh Gender}

\section{R.A. Kartini (21 April 1878-17 September 1904)}

R.A Kartini dianggap sebagai pelopor gerakan perempuan Indonesia. Menikah dengan Bupati Rembang R.M. A A. Djodjodhiningrat, Kartini sakit sepanjang bulan februari 1903. ${ }^{9}$ Dan meninggal setahun kemudian. Meskipun tidak banyak perbuatan nyata yang ia kerjakan, namun dengan semangat dan cita-citanya dalam sebuah karya surat-suratnya Habis Gelap Terbitlah Terang, ${ }^{10}$ sejumlah orang sepakat bahwa ia adalah salah satu tokoh gerakan wanita Indonesia. R.A Kartini memiliki pengaruh yang besar dalam dunia pergerakan wanita Indonesia. Banyak hal yang dikemukakannya dalam buku tersebut seputar persoalan dan masalah yang terjadi ditengah-tengah masyarakat Indonesia. Diantaranya kawin paksa, poligami, perceraian sepihak oleh suami, dan pingitan. Surat-suratnya kemudian dikumpulkan oleh beberapa kenalannya berkebangsaan Belanda yang dikumpul oleh Mr. J.M. Abendanon dan diterbitkan dalam tahun 1911 sebagai buku yang disebut Door Duisternis Tot Licht, yang kemudian diterjemahkan ke dalam bahasa Indonesia Habis Gelap Terbitlah Terang, dan dalam bahasa Inggris Letters Of A Javanese Princess. Maksud M.R. Abendanon ini adalah agar dapat menarik perhatian kepada khalayak publik untuk dapat memberikan bantuan mendirikan sekolah gadis Indonesia. Seperti yang dicita-citakan Kartini ketika itu. Buku itu ternyata mendapat perhatian yang cukup baik dan dengan dana penjualannya dapat mendirikan perhimpunan Kartinifounds di Den Haag yang bermaksud untuk mendirikan dan membantu sekolah anak perempuan. Dan pada akhirnya di akhir tahun 1913 didirikanlah sebuah sekolah Kartini yang pertama sekali di Semarang.

${ }^{8}$ Sharma, Arvin. Women In World Religions, (New York: State Of University, 1987), Terjemahan Syafaatun Al Mirzanah. Perempuan Dalam Agama-Agama Dunia, (Jakarta: Ditperta Depag RI, 2002). h. $289-290$

${ }^{9}$ Soeroto, Siti Soemandari. Kartini, Sebuah Geografi, (Jakarta: Penerbit Djambatan, 2001). h. 282

${ }^{10}$ Hasan, Hamka, DR. Tafsir Gender: Studi Perbandingan Antara Tokoh Indonesia Dan Mesir (Badan Litbang Dan Diklat Departemen Agama RI, 2009) h. 40 


\section{Zainab Al-Ghazali}

Dia terlahir di wilayah Al-Bihira, Mesir pada 1917. Zainab al-Ghazali adalah wanita luar biasa. Seperti Aisha Abd al-Rahman, tokoh asal Mesir ini begitu gigih memperjuangkan persamaan hak kaum perempuan berdasarkan keyakinannya, sesuai doktrin ajaran Islam yang benar. Oleh karenanya, sejarah mencatat Zainab lebih dikenal sebagai aktivis Islam ketimbang cendekiawan Islam. Ketika masih berusia sangat muda, 10 tahun, Zainab AlGhazali telah memperlihatkan kepandaian dan kelancarannya dalam berbicara di depan umum. Dan sepanjang hidupnya, dia lantas membentuk dirinya sebagai orang yang berhasil belajar secara otodidak. Ambisinya yang kuat dan tekadnya yang membara, membuatnya maju untuk mencapai jenjang pendidikan tinggi, pada saat kaum wanita pada saat itu jarang yang mengenyam pendidikan karena dianggap tabu.

Dia tidak setuju dengan ide-ide sekular tentang gerakan pembebasan perempuan. Meski demikian, Al-Ghazali tetap menghormati Sharawi dan menyebutnya sebagai seorang wanita yang memiliki komitmen dan keimanan yang baik. Saat usianya 18 tahun (1936), dia mendirikan Asosiasi Wanita Muslim untuk mengorganisasi kegiatan-kegiatan kaum perempuan yang sesuai norma-norma Islam dan ditujukan untuk kepentingan-kepentingan Islam.

Zainab Al-Ghazali selalu berusaha mengedepankan masalah keseimbangan antara hal-hal yang bersifat religius dan modern. Ia mendapat pendidikan agama pertama kali dari cendikiawan muslim terkemuka di Al-Azhar, Syeikh Ali Mahfuz dan Muhammad alNaggar.

Tidak lama setelah ia mendirikan Asosiasi Wanita Muslim, Al-Ghazali langsung melakukan sejumlah aksi dan mendapatkan dukungan dari Menteri Wakaf untuk mendirikan 15 mesjid dan belasan mesjid lainnya yang dibiayai oleh masyarakat umum.

Asosiasi yang didirikannya melahirkan generasi dai-dai wanita yang mempertahankan status perempuan dalam Islam serta meyakini bahwa agama mereka memberikan peluang sebesar-besarnya bagi kaum perempuan untuk memainkan peranan penting di tengah masyarakat, memiliki pekerjaan, masuk ke dunia politik dan bebas mengeluarkan pendapatnya. Dalam sebuah wawancara tahun 1981, dia mengemukakan bahwa Islam telah memberikan segalanya bagi kaum pria dan wanita. Islam memberikan kebebasan, hak ekonomi, hak politik, hak sosial, maupun hak pribadi kepada kaum Muslimah. Islam memberikan kaum wanita hak-hak tertentu di dalam keluarga yang tidak dimiliki oleh komunitas lain. Para Muslimah harus mempelajari Islam sehingga mereka mengetahui bahwa Islam telah memberikan segalanya kepadanya. Zainab juga meyakini bahwa Islam tidak pernah melarang kaum wanita untuk beraktivitas di masyarakat, bekerja mencari nafkah, masuk ke dunia politik dan mengungkapkan gagasan-gagasannya.

Dia percaya Islam mengizinkan mereka untuk memiliki harta benda, berusaha pada bidang perekonomian atau apapun kegiatan demi menunjang perkembangan masyarakat 
Muslim. Meski begitu, dia berpendapat bahwa tugas utama seorang wanita adalah menjadi ibu yang baik bagi anak-anaknya dan menjadi istri setiap bagi suaminya. Jangan ada apapun yang menghalangi kaum wanita untuk tidak menjalankan tugas yang satu ini. ${ }^{11}$

\section{Isu-Isu Gender}

Para lelaki dan perempuan adalah sama didalam islam berhubungan dengan ini sari martabat manusia, tanggung jawab dan penghargaan untuk perilaku pribadi dan berbagai hal yang berkaitan dengan hak milik, agama dan kesusilaan. ${ }^{12}$ Keturunan adam meliputi kedua-duanya yaitu para laki-laki dan perempuan yang sama dari sudut mereka diciptakan dan di dalam martabat mereka yang tak terpisahkan.

Upaya-upaya untuk mencapai penyetaraan dan keadilan gender terus dilakukan oleh aktivis perempuan, pada tahun 1980-an, melalui pendekatan "Gender a Development Aproach (GAD)". Dalam pendekatan ini tidak lagi melihat perempuan dan laki-laki dari perbedaan biologis akan tetapi memandang laki-laki dan perempuan secara sosial dan struktural dapat berpartisipasi dalam proses kehidupan, terutama partisipasi dalam kehidupan di ranah politik dan publik.

Partisipasi antara laki-laki dan perempuan dalam kehidupan berpolitik merupakan salah satu prinsip perjuangan para aktivis perempuan, sampai di amanatkan dalam konvensi penghapusan segala bentuk diskriminasi terhadap perempuan (Convention on the Ellimination of All Form of Discrimination Againt Women) atau CEDAW yang kemudian diadopsi oleh sidang umum PBB tahun 1979-an ditetapkan pada tahun 1981 dan pemerintah Indonesia sendiri juga telah meratifikasi melalui Undang-Undang Republik Indonesia no 7 tahun 1984 pada tanggal 24 Juli 1984 melalui lembar negara no 29 tahun 1984. Meskipun sampai saat ini perjuangan menuju kesetaraan dan keadilan masih belum optimal, karena diskriminasi sacara struktural dan kelembagaan masih kuat dalam kehidupan masyarakat. Perbedaan peran jenis kelamin tidak dapat diganggu gugat akan tetapi perbedaan peran gender masih bisa dirubah karena bergantung pada faktor sosial dan sejarah. Meskipun peran-peran jenis kelamin atau gender biologis yang dijalani oleh para perempuan dalam kehidupan rumah tangga dan masyarakat sering kali tidak terekspos atau diakui secara formal, hal ini disebabkan kuatnya kontruksi sosial serta pengaruh Hegemoni Budaya Patriakhi yang mengindikasikan pada mayoritas model pekerjaan laki-laki lebih terakui. Pendiskriminasian semacam ini semakin melemahkan sumber daya perempuan terlebih ketika para perempuan tidak mempunyai keinginan untuk merubah dan melakukan pembenahan-pembenahan sejak dini. Dan terkadang malah melakukan penyimpangan-penyimpangan perlakuan yang merugikan seperti:

\footnotetext{
${ }^{11}$ By Republika Contributor, Rabu, 15 Oktober 2008 pukul 13:22:00

${ }^{12}$ Faisar Ananda Arfa, Teori Hukum Islam Tentang Hak Asasi Manusia. Cet I. (Bandung: Cita Pustaka Media Perintis, 2008), h. 126
} 
1. Pergesekan organ seksual

2. Merokok

3. Anak perempuan bergaya laki-laki

4. Pelacuran ${ }^{13}$

Masalah gender merupakan masalah yang akhir-akhir ini sering diperbincangkan. Terutama oleh kaum perempuan itu sendiri, mengingat peran fungsi mereka yang tidak mau dinomorduakan oleh laki-laki. Fenomena alam yang terjadi dilapangan sampai-sampai para wanita berani mencalonkan diri sebagai kepala daerah terlebih lagi sebagai kepala negara. Seperti calon presiden Mesir sekarang, calan seorang pejuang dari turki yang bekerja sebagai pembaca berita acara yang bergabung dengan partai Refah (Kesejahteraan Islam) yang tak henti-henti meneriakkan perjuangan wanita. ${ }^{14}$ Pejuang kemerdekaan India Indhira Gandhi, Presiden Republik Indonesia ibu Megawati Soekarno Putri, perdana mentri Thailand dan banyak lagi para wanita yang tampil sebagai pemipin negara.

Dari pertengahan abad ke 19 ke depan perempuan dan laki-laki mulai membahas pembaharuan masyarakat dan arahnya yang tepat sesuai dengan ajaran Islam. Gagasan pembaharu Islam merupakan tanggapan kolonialisme barat, yang berpengaruh pada daerahdaerah muslim dengan taraf yang berbeda-beda. Baik perempuan dan laki-laki mempertanyakan pembatasan hukum dan sosial terhadap kaum perempuan dan khususnya yang berkaitan dengan hak-hak kaum perempuan yang untuk mendapatkan pendidikan, pemingitan perempuan, poligami, perbudakan perempuan dan dalam beberapa kasus pelacuran. ${ }^{15}$

Kaum muslimah yang memperoleh banyak dukungan negara dalam mewujudkan dan membela feminisme, terutama demi kepentingan diri mereka sendiri. Banyak yang berhasil memenuhi harapan kaum muslim dan harapan budaya dari perempuan-perempuan yang berpengaruh, yang menanggguhkan karirnya hingga setengah baya dan sering mendapatkan keberhasilan melalui hubungan dan pengaruh keluarga yang kuat.

Organisasi Muhammadiyah berdiri pada tahun 1912, menjadi lambang gerakan pendidikan dan pelayanan sosial yang apolitis. Dan Aisyiyah merupakan cabang lembaga organisasi keperempuanan yang memugkinkan menjadi mobilisasi dan motor gerakan perempuan Indonesia. Setelah era Soekarno partai-partai politik keagamaan dilarang dari empat partai Islam dileburkan menjadi satu partai yaitu, Partai Persatuan Pembangunan (PPP) meskipun demikian, sikap keberagaman terus meningkat di Indonesia. Begitu pula dengan busana muslim kontemporer. Organisasi-organisasi seperti Himpunan Mahasiswa

${ }^{13}$ Muhamad Al Jamal, Ibrahim. Fiqh Muslimat: Ibadah Muamalah. (Jakarta: Pustaka Amani, 1995). h. 395

${ }^{14}$ St. Martin, Terjemahan Yuliani Liputo, (Bandung: PT. Mizan Pustaka, 2009), A Heart Turned East : Antara Identitas Dan Integritas.(New york: press, 1998). h. 276

${ }^{15}$ John L. Esposito, Dunia Islam Modern jilid 2.terjemahan Eva (Bandung: Mizan, 2002). h. 103 
Islam (HMI) menghindari militansi meskipun memang isu gender sebagai isu secara integral terkait dengan identitas Islam.

Di Indonesia sebelumnya dikenal dengan istilah emansipasi wanita, yang konotasinya mirip dengan istilah gender, yaitu perjuangan menuntut persamaan hak-hak kaum wanita dengan kaum laki-laki dalam bermasyarakat. ${ }^{16}$ Isu gender ini tidak sering diartikan secara keliru. Isu gender ini merebak seiring dengan perkembangan arus globalisasi informasi dan perubahan politik nasional pasca reformasi. Reforrmasi memberi ruang gerak lebih bebas dan leluasa bagi setiap orang untuk menyampaikan aspirasi dan pemikirannya termasuk kaum wanita dengan gendernya. Kaum wanita menuntut hak-haknya dengan kaum lelaki dalam setiap aspek kehidupan.

Dalam pemahaman masyarakat yang menganut pola keibuan (maternal system), dimana peran kaum hawa lebih dominan ketimbang kaum pria, baik dalam masalah politik, sosial maupun ekonomi. Namun dalam masyarakat yang menganut sistem patriarchal beranggapan bahwa kaum pria yang lebih dominan dalam segala hal. ${ }^{17}$

Perjuangan keadilan dan kesetaraan gender di negeri ini telah berlangsung lama, sejak sebelum Indonesia merdeka hingga era reformasi. Tokoh-tokoh dan isunya pun beragam. Jika dikategorisasi secara periodik, gerakan feminisme Indonesia punya beberapa gelombang perjuangan wanita sebagai pelaku sejarah yaitu:

Pertama, dirintis oleh individu-individu yang tak terlembaga dan terorganisasi secara sistemik. Mereka bergerak sendiri-sendiri. Mungkin karena hambatan dan keterbatasan, seperti R.A. Kartini.

Kedua, Institusionalisasi gerakan dengan munculannya organisasi-organisasi perempuan seperti Persaudaraan Isteri, Wanita Sejati, Persatuan Ibu, Puteri Indonesia, Aisyi'ah Muhammadiyah, dan Muslimat NU. Ini berlangsung antara akhir 1920-an hingga akhir 1950-an. Isu yang berkembang masih sama dengan sebelumnya, yaitu emansipasi perempuan di berbagai bidang, termasuk penolakan poligami, pembenahan pendidikan, dan sebagainya. Organisasi perempuan Muhammadiyah, Aisyiyah, cukup gencar menyuarakan pentingnya perempuan mengambil bagian di ruang publik, karena mereka punya hak yang setara dengan laki-laki untuk meningkatkan kualitas diri berpolitik dan melakukan hal-hal yang berguna baik untuk diri pribadi sebagi fungsi awal maupun umum.

Hanya saja, gerakan perempuan pada periode ini belum maksimal. Perempuan cenderung tidak proaktif dalam proses-proses tersebut. Ini mungkin karena jumlah yang terlibat masih terbatas.

Sebagai tambahan atas praktik-praktik yang lebih umum. Wanita-wanita di berbagai belahan dunia banyak berperan aktif menjalankan tugas-tugas sosial. Seperti di Mesir,

\footnotetext{
${ }^{16}$ Hasbi Indra, Potret Wanita Shaleha, (Jakarta: Penamadani, 2004), h. 238

${ }^{17} \mathrm{Ibid}$, h. 239
} 
Sudan dan beberapa tempat lain, wanita (khususnya wanita yang dalam kategori menengah dan menengah kebawah) sesekali mengadakan apa yang disebut dengan upacar Zar, yaitu sebuah upacara yang dimaksudkan untuk membersihkan mereka dari apa yang dianggap pemilik roh. Bisa jadi pria mencemoohkan kegiatan terebut tetapi pada umunya mereka mempersiapkan biaya untuk berpartisipasi dalam upacara tersebut. ${ }^{18} \mathrm{Di}$ Irak sebagian wanita menikmati posisi yang didapatinya secara turun temurun sebagai Mollas (guru agama). ${ }^{19}$

\section{E. Implikasi Bagi Dunia Islam}

Islam dapat diterjemahkan sebagai sistem kehidupan yang mengantarkan manusia untuk memahami realitas kehidupan. Islam juga merupakan tatanan global yang diturunkan Allah sebagai rahmatan lil-'alamin. Sehingga sebuah konsekuensi logis bila penciptaan Allah atas makhluk-Nya laki-laki dan perempuan memiliki missi sebagai khalifatullah fil Ardh, yang memiliki kewajiban untuk menyelamatkan dan memakmurkan alam, sampai pada suatu kesadaran akan tujuan menyelamatkan peradaban kemanusiaan. Dengan demikian, wanita dalam Islam memiliki peran yang komprehensif dan kesetaraan harkat sebagai hamba Allah serta mengemban amanah yang sama dengan laki-laki.

Berangkat dari posisi di atas, muslimah memiliki peran yang sangat strategis dalam mendidik umat, memperbaiki masyarakat dan membangun peradaban. Mengantarkan masyarakat pada satu keunggulan peradaban. Mereka berperan dalam masyarakatnya untuk mengoptimalkan seluruh potensi yang ada pada diri mereka, sehingga kita tidak menemukan satu sisipun dari seluruh aspek kehidupan mereka terabaikan. Mereka berperan dalam setiap waktu, ruang dan tataran kehidupan mereka.

Masalah ras dan bahasa merupakan faktor untuk saling mengenal dan identitas alami. Manusia tidak dapat menghilangkan identitas tersebut, kemana ia pergi pasti membawanya. Wajah, bentuk, tubuh, bahasa, dialek dan lain-lainnya merupakan identitas alami manusia yang melekat pada tubuh.

Didalam Alquran tidak ada bahasa gender namun jika gender diartikan sebagai peran fungsi perempuan dan laki-laki, di Alquran menyebutkan dengan kata al-rajul dan annisa, dan lain lain. Misi Alquran juga membebaskan perbedaan dan diskriminasi setiap manusia. Warna kulit, sex, etnis, dan ikatan-ikatan primordial lainnya. ${ }^{20}$ Efek yang timbul dari perbedaan menimbulkan perdebatan. Terlebih Alquran mengangkat derajat wanita untuk dilindungi dan bukan dijadikan untuk pelampiasan hidup semata seperti yang dilakukan kaum Yahudi sebelum Islam hadir ditengah-tengah mereka. Prinsip gender dalam Islam merupakan, Pertama ; laki-laki dan perempuan sebagai hamba, Kedua ; manusia sebagai

\footnotetext{
${ }^{18}$ Sharma, Women in, h. 293

${ }^{19}$ Ibid., h. 293

${ }^{20}$ Mubarak, Zulfi. M. Ag, Sosiologi Agama: Tafsir Sosial Fenomena Multi Religius Kontemporer, Cet I, (Malang: UIN Malang Press, 2006). h. 49
} 
Khalifah, Ketiga ; manusia memiliki unsur ciptaan yang sama. ${ }^{21}$ Kita mengetahui bahwa perempuan dan laki-laki secara biologis memiliki perbedaan yang sangat tampak. Namun tidak dengan hal-hal sosial lainnya.

Wanita sering lebih dianggap lemah dalam fisik ketimbang laki-laki, padahal terkadang hal-hal yang fundamentalis ini sering dibantahkan oleh kenyataan yang ada walaupun terdapat disebahagian wanita. Namun banyak yang dialami wanita secara biologisnya yang tidak didapati pada laki-laki. Seperti melahirkan, hamil, menyusui, menstruasi, menopouse dan lain-lain. Oleh karena itu sering wanita ini dimaknai dengan negatif dan terkesan hanya melakukan kegiatan domestik saja (dalam rumah). Pendapat yang lebih ekstrim lagi bahwa terdapat pandangan yang melihat wanita sebagai sumber dosa dan juga iblis kecil. Padahal martabat dan kehormatan laki-laki dan perempuan harus sama secara identik. Dan lebih ekstrim lagi bahwa pendapat di dalam doktrin agama Yahudi yang mengatakan bahwa akibat dosa hawa di surga membuat kaum wanita secara keseluruhan akan menanggung sepuluh beban dosa atau penderitaan, yaitu :

1. Perempuan akan mengalami siklus menstruasi, darah menstruasi di anggap darah tabu, dan perempuan yang sedang mens menurut agama Yahudi harus di asingkan dan hidup dalam gubuk khusus. Atau mengasingkan diri ke goa-goa, tidak boleh bergabung dengan keluarganya, tidak boleh melakukan hubungan seks, dan tidak boleh menyentuh jenis makanan tertentu. Bahkan tatapan mata wanita yang sedang mens disebut pula mata iblis. Dianggap dapat menimbulkan bencana. Wanita yang sedang mens memiliki identitas tersendiri agar dapat diketahui orang banyak. Seperti dengan menggunakan kosmetik, cadar/jilbab, dan lain-lain.

2. Perempuan yang melakukan hubungan seks pertama sekali akan mengalami rasa sakit.

3. Perempuan akan mengalami rasa penderitaan dalam mengasuh dan memelihara anakanaknya, anak-anak akan membutuhkan perawatan, pakaian, kebersihan dan pengasuh sampai dewasa. Dan ibu akan merasa risih jika anaknya tumbuh dan berkembang tidak sesuai dengan yang diharapkannya.

4. Perempuan akan merasa malu terhadap tubuhnya sendiri.

5. Perempuan merasa tidak akan leluasa bergerak ketika kandungannya berumur tua.

6. Perempuan akan merasa sakit saat melahirkan.

7. Perempuan tidak boleh mengawini lebih dari satu pria.

8. Perempuan masih akan merasakan hubungan seks lebih lama sementara suaminya tidak kuat lagi.

9. Perempuan sangat berhasrat melakukan hubungan seks terhadap suaminya tetapi amat berat menyampaikan hasrat itu kepada suaminya.

10. Perempuan lebih suka tinggal dirumah. ${ }^{22}$

\footnotetext{
${ }^{21}$ Ibid., h. 51

${ }^{22}$ Indra, Potret., h. 261-262
} 
Keseragaman sering diartikan dengan kesederajatan namun sebenarnya secara keseragaman laki-laki dan perempuan jelas sama akan tetapi tidak dalam konteks kesederajatan. ${ }^{23}$ Dan ini yang sering menimbulkan polemik terus menerus. Sayyid Qutb mengatakan bahwa martabat merupakan hak alami setiap individu. Anak adam sejak awal telah dimuliakan bukan karena atribut personal mereka dan bukan pula status sosial mereka, tetapa sematamata mereka manusia: "kemuliaan karenanya hak absolut setiap orang". ${ }^{24}$

Alquran yang diturunkan Allah melalui nabi Muhammad Saw, mengharapkan agar seluruh umat manusia terutama kaum pria agar memperlakukan wanita lebih baik dan terhormat sesuai dengan prinsip ajaran kesetaraan pria dan wanita sebagai makhluk ciptaan Tuhan Yang Maha Mulia, sesuai dengan ayat Allah dalam surat Al-Hujarat 13, yang artinya:

"Hai manusia, sesungguhnya kami menciptakan kamu dari jenis orang laki-laki dan perempuan. Dan menjadikan kamu berbangsa-bangsa dan bersuku-suku. Supaya kamu saling kenal mengenal, sesunguhnya orang yang paling mulia diantara kamu disisi Allah adalah orang yang paling bertaqwa. Sesungguhnya Allah maha mengetahui lagi maha mengenal."

Ayat diatas menggambarkan bahwa kedudukan pria dan wanita sederajat. Adanya perbedaan pria dan wanita dibidang hukum bukan karena lelaki itu lebih mulia dari pada wanita melainkan karena keimanan dan ketaqwaan kepada Allah Swt. Secara garis besar berbicara tentang gender dalam Islam tidak terlepas dari pernikahan, perceraian, warisan dan kepemikikan harta.

\section{F. Penutup}

Secara sedehana dapat kita katakan bahwa kehidupan ini tidak akan berjalan selaras, serasi dan seimbang jika kesetaraan dan keseragaman ditinggalkan begitu saja. Artinya bahwa memang secara alamiah perbedaan itu pasti selalu ada seperti warna kulit, ras, budaya bahkan tidak luput Tuhan menampilkan dua jenis kelamin manusia yang berbeda pula. Yang seakan-akan menuntut kita untuk mengkaji lebih dalam lagi apa sebenarnya makna dan nilai dari perbedaan tersebut. Ada yang menafsirkan dengan berbagai disiplin ilmu mereka yang membuat perbedaan makna dan bahkan menjadi alat untuk melakukan hal-hal serta kepentingan mereka masing-masing.

Wanita muslim saat ini idealnya bersifat konservatif baik dalam hal moral maupun keagamaan dan menegaskan nilai nilai mutlak atas sistem Islam yang benar bagi hubungan kemanusiaan. Karena mereka ingin mengambil keuntungan sepenuhnya atas kesempatan pendidikan dan profesi yang tersedia. Gender berarti jenis kelamin.

Kesetaraan dan keseragaman namun bukan kesederajatan. Pemahaman gender

\footnotetext{
${ }^{23}$ Ibid... h. 75

${ }^{24}$ Arfa, Teori Hukum, h. 55
} 
terkadang menjadi alat perempuan dalam melakukan hal-hal positif dalam mengantarkan kehidupan yang lebih baik. Dan Islam tidak pernah canggung dalam mengadopsi kata-kata gender karena jauh sebelum istilah ini lahir Islam telah bicara banyak tentang peran fungsi dan tanggung jawab para wanita shaleha.

"Barangsiapa yang mengerjakan amal shalih, baik laki-laki maupun perrempuan dalam keadaan beriman, maka sesungguhnya akan kami berikan kepadanya kehidupan yang baik" (Qs. An-Nahl:97) 


\section{DAFTAR PUSTAKA}

Hasbi Indra, Potret Wanita Shaleha, ( Jakarta: Penamadani, 2004).

Katimin, Mozaik Pemikiran Islam, (Bandung: Cita Pustaka Media Perintis, 2010).

Hilary M. Lips, Sex \& Gender An:Intruduction (London:Mayfield Publishing Company,1993).

Ch. Mufidah, Psikologi Keluarga Islam:Berwawasan Gender. (Yogyakarta:UIN Malang Press, 2008).

Anne Borroedale, Tugas Rangkap Wanita: Mengubah Sikap Orang Kristen, (Jakarta: PT. BPK Gunung Mulia, 1997).

Maria Ulfa Subadio, Peranan Dan Kedudukan Wanita Indonesia. Cet IV, (Yogyakarta: Gajah Mada University Press, 1994).

Arvin Sharma, Women In World Religions, (New York: State Of University, 1987), Terjemahan Syafaatun Al Mirzanah. Perempuan Dalam Agama-Agama Dunia, (Jakarta: Ditperta Depag RI, 2002).

Siti Soemandari Soeroto, Kartini, Sebuah Geografi, (Jakarta: Penerbit Djambatan, 2001).

Hamka Hasan, Tafsir Gender: Studi Perbandingan Antara Tokoh Indonesia Dan Mesir (Badan Litbang Dan Diklat Departemen Agama RI, 2009).

By Republika Contributor, Rabu, 15 Oktober 2008 pukul 13:22:00.

Arfa, Faisar Ananda, MA. Dr. Teori Hukum Islam Tentang Hak Asasi Manusia. Cet I. (Bandung: Cita Pustaka Media Perintis, 2008).

Ibrahim Muhamad Al Jamal, Fiqh Muslimat,Ibadah Muamalah. (Jakarta: Pustaka Amani, 1995).

St. Martin, Terjemahan Yuliani Liputo, (Bandung: PT. Mizan Pustaka, 2009), A Heart Turned East : Antara Identitas Dan Integritas.(New york: press, 1998).

John.L.Esposito, Dunia Islam Modern, jilid 2, terjemahan Eva (Bandung: Mizan, 2002).

Zulfi Mubarak, Sosiologi Agama: Tafsir Sosial Fenomena Multi Religius Kontemporer, Cet I, (Malang: UIN Malang Press, 2006). 